\title{
Nineteenth-century Romanian Translations: Hamlet for the Page or for the Stage ${ }^{1}$
}

\begin{abstract}
Taking as a starting point the opposition between translation for the page and translation for the stage, the present paper sets out to consider the strategies employed by $19^{\text {th }}$-century Romanian translators when rendering Shakespeare's plays into Romanian. I will discuss two translations of Hamlet: the first, a scholarly, page-oriented translation published by Adolf Stern in 1877; the second, a domesticating stage-oriented translation produced by actor Grigore Manolescu for his own production of Hamlet, at the National Theatre of Bucharest, in 1881. The paper will address such issues as foreignizing vs. domesticating strategies of translation, transparency, the status of the translator as well as the various elements that make a translation for the page differ from a translation for the stage.
\end{abstract}

Keywords: Hamlet, page-oriented vs. stage-oriented translation, $19^{\text {th }}$ century, Romanian principalities

The commonly applied distinction that separates drama translation (a reader--oriented translation) from theatre translation (a stage-oriented translation) ${ }^{2}$ currently used nowadays, was also present - albeit not under the form of precise theoretical statements - in the practice of translating Shakespeare's plays into Romanian in the $19^{\text {th }}$ century. The two translations of Hamlet examined in this paper belong to the last decades of the $19^{\text {th }}$ century and were rendered into Romanian by Adolf Stern in 1877 and by the Romanian actor Grigore Manolescu in 1881. I argue that we can consider Stern's Hamlet to be a foreignizing, page-oriented translation that aims to preserve the cultural and linguistic difference of the original, and Grigore Manolescu's a domesticating, stage-oriented version that

1 Research for this article was supported by the UEFISCDI grant, PN III - IDEI, no.1/2017, Borderland Circulation of Shakespeare.

2 S. Bigliazzi, Introduction, in: Theater Translation in Performance, S. Bigliazzi, P. Ambrosi, P. Kofler (eds.), New York 2013, p. 5. 
attempts to assimilate the foreign text, by adapting and adopting it, by rendering it fluent and easily comprehensible. My understanding of the conceptual opposition between foreignization and domestication is tributary to Lawrence Venuti's discussion of these two strategies of translation in his seminal book The Translator's Invisibility. ${ }^{3}$

As in most other East-European countries, translations from West European literature and particularly from Shakespeare were strongly encouraged by all $19^{\text {th }}$ -century Romanian scholars, being considered the proper way of disseminating Western culture in the Romanian principalities and of synchronizing Romanian culture with the Western consciousness. ${ }^{4}$ In the introduction to his translation of Hamlet, Adolf Stern, the first translator of Hamlet into Romanian from English, stresses the significance of translations from foreign literatures for the development of a national language and literature as well as the importance of taking part in the great flurry of translation activity that furthers the exchange of ideas among European cultures ${ }^{5}$ :

There is nothing that can be of more help to the heightening of this movement (i.e. the new Romanian literary movement) than the translation of the models offered to us by foreign literatures. Besides the abundance of ideas and forms to which they give rise in our mind and our language, we can also acquire models worthy to be imitated and the urge to imitate them. ${ }^{6}$

After a period of abusive foreignization of translations, between 1840-1870, when, in order to assert the Latinity of the Romanian language against the monopolizing Slavic influences, translators made excessive use of words of Latin and French origin, at the turn of the $20^{\text {th }}$ century Romanian scholars started to advocate the use of the current autochthonous Romanian language, which included words of both Slavic and Latin origin. A good translation had to be fluent and accurate. Writing about the manner of translating Shakespeare into Romanian, critic Ion Botez insisted that Shakespeare had to be "împământenit" (the verb "a împământeni" means "to put down roots in the soil, to take root, to get adapted"). ${ }^{7}$ Therefore, the most appropriate method of translating Shakespeare into Romanian was domestication, a translation strategy that favoured the use of a fluent, familiar language and focused on making Shakespeare "sound Romanian".

Adolf Stern goes against this domesticating trend by means of the translation choices that he adopts. His Hamlet is the first scholarly Romanian translation of the play and the first to use Shakespeare's original text and not a French or German intermediary. Hamlet had been previously translated into Romanian by Ioan Barac in the 1820 s, a manuscript translation based on several German adaptations, and by D.P. Economu, who published his translation in Bucharest

3 L. Venuti, The Translator's Invisibility: A History of Translation, London-New York 2002.

4 E. Lovinescu, Istoria Civilizației Române Moderne, București 1972, p. 15.

5 Unless otherwise indicated, all translations from Romanian and French are mine.

6 A. Stern, Preface, in: W. Shakespeare, Hamlet prinţul Danemarcei. Tragedie in 5 acte, A. Stern (transl.), București 1877, p. vii.

7 I. Botez, Shakespeare Tradus, "Viața Românească" 1924, no. 1-3, p. 2. 
in 1855 and used as an intermediary the popular French adaptation produced by Alexandre Dumas and Paul Meurice for the Théâtre Historique in Paris, in $1847 .{ }^{8}$ In the extensive introduction that precedes the translation, Stern, a self-conscious translator, aware of the difficulty of his task, writes about the choices that he made when translating Hamlet and offers a critical reading of the play, manifestly informed by German Romantic aesthetics. Echoing writers such as Lessing and A.W. Schlegel, Stern praises Shakespeare's genius and his skill in portraying true-to-life characters capable of arousing sympathy and passionate responses in the audience, his craft in drafting complex and dynamic plots. Stern's interpretation of the eponymous hero relies heavily on Goethe's famous reading of the play and consequently presents Hamlet as a melancholic prince, who lacks the energy, the strength of will and the ambition to perform the great task imposed upon his soul. He feels incompetent to carry out his difficult mission and, therefore, he keeps delaying his revenge against Claudius. In the end, the translator expresses his wish that the Romanian audience may soon see Hamlet performed at the National Theatre of Bucharest, being confident that only thus would his readers manage to grasp the depths of the play. Whether he envisaged his own translation as a possible text to be used for such a future performance is difficult to tell.

Stern's views on translation are also tributary to A.W. Schlegel's understanding of Shakespearean drama as organic poetry. According to Schlegel, every formal detail is relevant and calculated to serve the total effect; therefore, a faithful translation of the original demands taking into consideration not only the semantic meaning, but also the aesthetic form, which represents an essential part of the whole, since it carries a distinctive part of the overall meaning. The ideal translation has "to recreate the entire organism of the source text by a corresponding organism of the target text". ${ }^{9}$ In a similar vein, Stern concludes that he could not imagine a Shakespearean translation that would lack the vigorous blank verse and harmonious rhythm of the original and that he managed to insert in that restricted form the entire body of the original. ${ }^{10}$ Several years later, speaking about his translation, which he used to revise periodically (he published two revised editions in 1905 and 1922), Stern explains his choice: "I had chosen the blank verse of the English original, because I found its rhythm alert and vigorous and because I believed that the form is also an integral part of a work of art, shaping its true physiognomy" and commentaries before choosing the English edition that he employed for his translation.

Stern's decision to preserve both the original metrical form, the iambic pentameter, and the blank verse (a daring and challenging task at that time) represents

8 O.-A. Zaharia, The First Romanian Translations of Hamlet, "American, British and Canadian Studies" 2011, no. 17, pp. 106-120.

9 W. Habicht, The Romanticism of the Schlegel-Tieck Shakespeare and the History of $19^{\text {th }}$ Century German Shakespeare Translation, in: European Shakespeares. Translating Shakespeare in the Romantic Age, D. Delabastita, L. D’hulst (eds.), Amsterdam-Philadelphia 1993, p. 46.

10 A. Stern, Preface ..., op. cit., s. xxii.

11 Idem, Din viața unui evreu-român, București 1915, p. 192. 
the first instance of foreignization, given the fact that Shakespeare had been so far translated into Romanian either in rhymed alexandrines or in prose, following the French, neoclassical method of translation which was still dominant in many other parts of Europe. Undoing the French-sourced model, Stern preferred to move the target language reader towards the author and the source-language text rather than domesticate his translation, opting for conveying the conciseness and compactness of the English verse at the expense of fluency. ${ }^{12}$ As Nicoleta Cinpoeș argues, in his attempt to "inform the Romanian reading public about the Englishness of Hamlet in terms of language, theatrical tradition and reception of the play", Stern "was excessively preoccupied with transmitting the exact meaning, the particular atmosphere of the play and the play's English specificity, riding roughshod over the equivalent specificity of his target language". ${ }^{13}$ This seems to have been the reason why Stern's translation was never performed on stage, failing to stir the interest of Romanian theatre practitioners. His very rigorous, page-oriented translation must have been deemed unsuitable for the stage; by lacking fluency, it implicitly lacked the quality of performability, the text's appropriateness for the stage.

It was precisely the need of a stage-oriented translation of Hamlet that prompted actor Grigore Manolescu to produce his own version of the play in 1881. Performing Hamlet on the Romanian stage had been Manolescu's greatest dream ever since he was a teenager and saw the Queen's closet scene performed by two of his older colleagues in his drama class. Fourteen years passed until he was given the chance to impersonate the Prince of Denmark. According to the actor's own statements, he devoted those years to the study, translation and understanding of Hamlet..$^{14} \mathrm{He}$ considered the Shakespearean play to be "both a literary and a theatrical enigma" that required thorough knowledge, powerful feelings and special performing skills in order to be successfully rendered on stage. ${ }^{15}$ When asked in an interview about the qualities one needs in order to perform Hamlet, he answered curtly: "Patience and courage; I wished to perform this role for a very long time, and after fourteen years I managed to fulfil my wish". ${ }^{16}$ A contemporary journalist, Ionescu-Gion, commented on Manolescu's outstanding success as Hamlet: "Talent accompanied by study can work wonders: studying assiduously for several years, with the perseverance and patience of the artist who wants to accomplish more than any other person". ${ }^{17}$

Although Manolescu's translation was never published, its text must have been extremely familiar to all theatre goers, since Manolescu's production was a tremendous success and dominated the Romanian stage until his premature death in 1892. As writer Liviu Rebreanu noticed in a 1913 review celebrating the one

12 L. Venuti, op. cit., p. 2.

13 N. Cinpoeș, Shakespeare's Hamlet in Romania 1778-2008: A Study in Translation, Performance and Cultural Appropriation, Lewiston 2010, pp. 27, 29.

14 V. Brădățeanu, Grigore Manolescu, București 1958, p. 97.

15 Ibid.

16 Ibid.

17 T. Șhyperl, Grigore Manolescu, București 1960, p. 237. 
hundredth representation of Hamlet on the stage of the National Theatre of Bucharest, Manolescu as Prince Hamlet was so popular and famous, that it took four years after his death until another actor, Constantin Nottara, managed to pluck up his courage and portray a new Hamlet on the Romanian stage. ${ }^{18}$

Using Pierre Letourneur's French prose translation of the text, Manolescu's version is characterized by a simplification of the action through omissions and rearrangements of scenes. The title on the front-page of the manuscript reads Hamlet - A tragedy in 5 acts and 13 tableaus. Manolescu's rendering focuses on Hamlet's deep and complex inwardness, on his emotional responses to the world around him. Consequently, the actor-translator frequently cuts any scenes or details that could eclipse Hamlet's centrality and complexity. Thus, he feels no frustration in omitting the last scene of the play - the arrival of Fortinbras - believing that it destroyed the powerful effect of Hamlet's death. Other parts, such as the first scene of the play, were probably deliberately omitted in order to meet the time and space requirements of the stage.

In sharp contrast to Stern's scholarly translation, Manolescu's free rendering reads easily; it is fluent and unmarked by lexical or syntactical peculiarities, managing to create the illusion of transparency characteristic of the domesticating methods of translation. ${ }^{19}$ Manolescu attempted to produce a naturally sounding colloquial text which lent itself to performance on stage and allowed actors to portray living people whose ways and motives could be easily comprehended by the audience. His translation uses an energetic Romanian language and manages to sound clear, concise and kinetic.

As an illustration of these two different translation strategies, the translation of the final lines of Hamlet's famous interpellation of the Ghost will be considered:

a. I'll call thee Hamlet,/King, father, royal Dane; O, answer me!/Let me not burst in ignorance; but tell/Why thy canoniz'd bones, hearsed in death,/Have burst their cerements; why the sepulchre,/Wherein we saw thee quietly in-urn'd,/Hath op'd his ponderous and marble jaws/To cast thee up again! What may this mean, That thou, dead corpse, again in complete steel/Revisits thus the glimpses of the moon,/Making night hideous, and we fools of nature/So horridly to shake our disposition/With thoughts beyond the reaches of our souls?/Say, why is this? Wherefore? What should we do? ${ }^{20}$

\section{b. Adolf Stern (1877)}

Ți-oi zice Hamlet, Rege, tată, Domn/Al Danemarcei. O respunde'm/Nu mă lăsa să per în neștiință,/Ci zi, de ce sfințita ta țărână/Ascunsă-n moarte, vălul său a rupt!De ce mormântu'n care te-am văzut/Culcat în pace, ş-a deschis gătlejul/Cel greu de marmoră, spre a te svârli/ Afară! Ce să însemneze oare,/Că tu, trup mort, vii în deplin oțel/Să visitezi ear licurirea lunei/Și noaptea schilodind-o, nouă, proștii/Naturei, să ne sgudui firea cu/Gândiri teribile, cari covărșesc/Inteligința sufletelor noastre?/De ce aceasta? Spune. Ce să facem?21

18 L. Rebreanu, Hamlet se reprezintă mâine pentru a suta oară, "Rampa" 1913, 2.02, pp. 1-2.

9 L. Venuti, op. cit., p. 2.

20 W. Shakespeare, Hamlet ..., op. cit., I.4.23-35.

${ }^{21}$ A. Stern, Preface ..., op. cit., p. 26. 
(Back translation of the lines in bold: What may this mean?/That you, dead corpse, come in complete steel/To visit again the glimmer of the moon/ And crippling the night, to us, fools/Of Nature, shake our nature with/Terrible thoughts that overwhelm/ the intelligence of our souls).

\section{c. Grigore Manolescu (1881)}

Te voi numi Hamlet, rege, tată, stăpânitorul Danemarcei! Oh! Răspunde! Nu-mi lăsa inima să se sfâşie de nerăbdare. Spune-mi pentru ce venerabelele tale oseminte îngropate în pamânt, au sfâşiat giulgiu funebru? Pentru ce mormântul în care te-am văzut dormind în pace, a ridicat piatra de marmoră ca să te arunce iar la viață? Care să fie obiectul acestei minuni, ca tu corp mort să te arăți din nou razelor lunii și astfel să îndoiești spaima nopței? Spune pentru ce aceasta? Cu ce scop? Ce trebuie să facem ${ }^{22}$

(Back translation of the lines in bold: What might the purpose of this miracle be, that you, dead corpse, should show yourself again in the moon's rays and thus double the horror of the night? Say, why is that? What for? What should we do?)

\section{d. Pierre Letourneur (1835)}

Je t'appellerai Hamlet, roi, père, monarque danois. Oh! Réponds-moi; ne laisse pas mon cœur se rompre d'impatience. Mais dis-moi pourquoi tes vénérables ossements inhumés dans la terre, ont déchiré leurs linceuls funèbres? Pourquoi la tombe où nous t'avons vu paisiblement enseveli, a-t-elle soulevé le poids de ses marbres énormes pour to rejeter al la vie. Quel peut être l'objet de ce prodige, que toi, corps trépassé, de nouveau revêtu de fer, tu revisites encore les pales rayons de la lune, redoublant l'horreur de la nuit? Et nous, jouets de la nature, pourquoi sommes-nous agités par de si horribles secousses, et affligés de pensées qui passent la portée de notre âme? Dis, pourquoi cela? Pour quel objet? Que devons-nous faire?23

(Back translation of the lines in bold: What might the purpose of this miracle be, that you, dead corpse, clad in steel once more, should revisit again the moon's pale rays and thus double the horror of the night? And why are we, toys of nature, shaken by such horrible jolts and tortured by thoughts that overcome the reaches of our souls? Say, why is that? What for? What should we do?)

Stern's version, which is faithful to the original in terms of meaning and prosodic form, sounds "strange" to a Romanian audience, although the text is not incomprehensible, while Manolescu's freer prose version is more natural and closer to the Romanian syntax. In order to provide a fluent version, Manolescu omits certain lines that are either too difficult to express in familiar Romanian or whose subtle meaning the theatre audience might not have been able to grasp. Thus, in the passage quoted above, Manolescu follows closely the first part of Letourneur's text (which is a faithful prose translation of Shakespeare's lines) but chooses to leave out precisely those lines in the play ("Et nous, jouets de la nature, pourquoi sommes-nous agités par de si horribles secousses, et affligés de

22 W. Shakespeare, Hamlet, tragedie in 5 acte si 13 tablouri, G. Manolescu (transl.), The National Theatre of Bucharest Library, Ms. 124, 1881, p. 19.

${ }^{23}$ Idem, Hamlet, in: Oeuvres dramatiques de Shakespeare, vol. 2, [Pierre-Prime-Félicien] Letourneur (trad. de l'anglais), Paris 1835, p. 12. 
pensées qui passent la portée de notre âme?") that make Stern's translation sound syntactically peculiar and semantically obscure. In his attempt to preserve the iambic pentameter, Stern often ends the line with a conjunction or preposition, which makes the text sound unnatural in Romanian.

Nevertheless, it is not only in terms of syntax and word order that Stern foreignizes the text, but also at the lexical level. He sometimes coins new Romanian words based on the English ones. Thus, he translates "the sledded Polacks" as "insăinaţiii", ${ }^{24}$ an invented word derived from the Romanian sanie (sledge). The constant use of calque formations such as "în deplin oțel" (in complete steel), "să visitezi ear licurirea lunei" (revisits thus the glimmer of the moon), "îi voi vorbi cuțite" (I will speak daggers to her $)^{25}$ hardly produces any illusionistic effect of transparency. ${ }^{26}$ On the contrary, they make readers fully aware that what they are reading is indeed a translation and not the original.

Another relevant example can be found in the scene where Claudius, granting Laertes permission to leave for France, tells him:

a. Take thy fair hour, Laertes; time be thine,/And thy best graces spend it at thy will! (act 1, scene 2).

b. Regele Ia'ți ora priincioasă dar, Laertes, ['Take your favourable hour...']/Și timpul tău și darurile tale/Useasă-le cum ți-o plăcea mai bine. ${ }^{27}$

c. Regele Pleacă când vei voi. Laerte, ai tot timpul, dispune de el, precum și de tot ce-ți poate plăcea sau face fericit ['Leave whenever you want...']. ${ }^{28}$

Unlike Manolescu's version (c), which opts for a familiar, naturally sounding Romanian expression, Stern's translation (b) is literal, using once more a calque formation. Stern was severely criticized by certain contemporary reviewers precisely for this type of word-for-word translation, which was deemed to be mechanical and strange. A Romanian critic and historian, A.D. Xenopol, winds up his review of Stern's translation by stating that:

This kind of bondage to the original is always detrimental, especially when one has to translate into Romanian from a Germanic language which, being characterised by the fact that it can express numerous ideas in few words, can cause a lot of difficulties when one intends to keep close to the original. ${ }^{29}$

According to Lawrence Venuti, it is by means of such close adherence to the source text that the translator can preserve the cultural and linguistic difference of the original, Stern's initially avowed intention. He also argues that a translator can foreignize his text by using a discursive strategy that deviates from the prevailing hierarchy of dominant discourses (i.e. dense archaism) ${ }^{30}$ which is precisely what

${ }^{24}$ I, 1, p. 3.

25 III, 2, p. 88.

26 L. Venuti, op. cit., p. 1.

27 A. Stern, Preface ..., op. cit., s. 10.

28 W. Shakespeare, Hamlet, tragedie in 5 acte..., op. cit., p. 3.

29 A.D. Xenopol, Hamlet Prințul Danemarcei, tragedie in 5 acte de William Shakespeare, A. Stern (tradusă), "Convorbiri Literare" 1877, no. 7, October, p. 276.

30 L. Venuti, op. cit., pp. 122-123. 
Stern does when he frequently uses informal words, regionalisms and old, autochthonous Romanian expressions. Thus, he uses litfani instead of leși or poloni ('Polacks'), ${ }^{31}$ acioaie instead of bronz ('brazen cannons'), ${ }^{32}$ suduros instead of nădușit ('sweaty'), priincios instead of favorabil or prielnic ('fair', 'favourable') ${ }^{33}$ and its antonym nepriincios, bufnoasă instead of ursuză ('peevish'), ${ }^{34}$ conşcolar instead of coleg/camarad de școală ('fellow student'), ${ }^{35}$ etc. Stern's lexical and stylistic choices as well as his opting for the iambic pentameter clearly represented a deviation from the current usage and challenged the dominant French discourses of the time. Two decades later, in his Memoirs, the translator himself described the cultural and literary ideas that dominated the period when he undertook the task of translating Hamlet as follows:

Finally, there were quite a few literary persons who maintained that our language does not allow the blank verse! We were living in that period when French literature had an omnipotent influence not only on our way of thinking, but also on our language, which, departing from its point of origin, got so overloaded with neologisms that it became, according to Nicolae Iorga, a sort of French-Romanian volapük. Moreover, even the form had to be subjected to the French model. And since the rhymed alexandrine was the time-honoured verse of the French classical playwrights, we also had to imitate it, although we did not have this tradition. ${ }^{36}$

These ideas turned Stern into an unnamed supporter of the new, German-influenced cultural and literary direction initiated by Titu Maiorescu and the Junimea society. Junimea was a literary society formed in Iași (1863) by a group of five young intellectuals, who, having just returned from their studies abroad (mainly in Germany), wished to invigorate and stimulate the cultural life of their city. The "Junimists", whose indisputable mentor was the aesthetician and literary critic, Titu Maiorescu, struggled against mediocrity and searched to impose the aesthetic criterion in the setting of a hierarchy of values. Maiorescu emphasized the importance of modernizing and consolidating the Romanian language by standardizing its orthography and grammar and by enriching its vocabulary with neologisms borrowed from other languages only when necessary. By 1867 , the cultural review published by them, Convorbiri literare, had become the most important literary publication in the history of Romania and vastly contributed to the promotion of the great classics of the Romanian literature. Reviewing Stern's translation of Hamlet in Convorbiri literare, Titu Maiorescu noticed:

Mr. Stern's translation is extremely good. His appropriate choice of words, the careful search for those old expressions, which are often better and more meaningful than the French neologisms, by which he tried to replace the superficial conversation of our modern salons, testify to his thorough study of the Romanian language in all its lexical forms. ${ }^{37}$

31 I, 1, p. 4.

32 I, 1, p. 3.

33 I, 2, p. 10.

34 I, 2, p. 12.

35 I, 2, p. 14.

36 A. Stern, Din viața..., op. cit., pp. 191-192.

37 T. Maiorescu, Traducerea lui Hamlet de D. Adolf Stern, “Timpul” 1877, no. 129, pp. 3-4. 
Maiorescu praised precisely the translator's inspired choice of words and supported his method of translation which most definitely went against the grain. However, Maiorescu's support was not only linguistically but also politically motivated. Adolf Stern was a Jew and an active political fighter for the emancipation of the Jews in Romania at the time when, in Romania, as in the largest part of Europe, the "Jewish Question" (the debate pertaining to the appropriate status and treatment of Jews in society) was one of the most ardent political issues of the time. Maiorescu was one of the few prominent figures in Romania who opposed anti-Semitism and favoured a positive solution to the "Jewish Question". By stressing Stern's thorough knowledge of the Romanian language, Maiorescu indirectly defended his translation against such subtly anti-Semitic comments as those of A.D. Xenopol.

In this context, one can assume that Stern's choice of a foreignizing strategy of translation might have also been fueled by reasons that moved beyond his main philological interest. By registering the cultural and linguistic difference of the English text, he implicitly advocated the importance of preserving the cultural and linguistic difference of any other foreign text/people. Thus, Stern may have used foreignization in order to subtly draw the attention of a rather anti-Semitic Romanian society to the importance of conserving the cultural difference of all people, Jews included.

As previously mentioned, Stern published two more and considerably revised versions of his translation of Hamlet - in 1905 and 1922 - in which he addressed some of his peers' criticisms and amended several mistakes and passages, in a philologically driven attempt to improve his translation from one edition to the next. His version remained a cornerstone, page-oriented translation, being considered by later critics such as C.S. Checkley and Vladimir Streinu "the only scholarly translation into Romanian of the complete English text... unchallenged until 1948". ${ }^{38}$ At the same time, Manolescu's domesticated, or in Jean-Michel Déprats' terms, "creative translation", ${ }^{39}$ dominated the Romanian stage for the next thirty years, being employed by all Romanian actors performing Hamlet in the first two decades of the twentieth century. Thus, both translations circulated concomitantly, moving the tension between stage and page well into the twentieth century.

\section{References}

Bigliazzi S., Ambrosi P., Kofler P. (eds.), Theater Translation in Performance, New York 2013.

Botez I., Shakespeare Tradus, "Viața Românească” 1924, no. 1-3, pp. 32-77.

Brădățeanu V., Grigore Manolescu, București 1958.

${ }^{38}$ C.S. Checkley, qtd. in: V. Streinu, Preface to Tragedia lui Hamlet, Prinț de Danemarca, București 1965 , p. xiv.

${ }_{39}$ J.M. Déprats, Translating Shakespeare's Stagecraft, in: Shakespeare and the Language of Translation, T. Hoenselaars (ed.), The Arden Shakespeare: Shakespeare in Language, London 2004, pp. 134. 
Checkley C.S., Rumanian Interpretations of Hamlet, "The Slavonic and East European Review" 1965, vol. XXXVII, pp. 413-429.

Cinpoeș N., Shakespeare's Hamlet in Romania 1778-2008: A Study in Translation, Performance and Cultural Appropriation, Lewiston 2010.

Déprats J.M., Translating Shakespeare's Stagecraft, in: Shakespeare and the Language of Translation, T. Hoenselaars (ed.), The Arden Shakespeare: Shakespeare in Language, London 2004, pp. 133-147.

Habicht W., The Romanticism of the Schlegel-Tieck Shakespeare and the History of $19^{\text {th }}$ Century German Shakespeare Translation, in: European Shakespeares. Translating Shakespeare in the Romantic Age, D. Delabastita, L. D'hulst (eds.), Amsterdam-Philadelphia 1993, pp. 45-53.

Lovinescu E., Istoria Civilizației Române Moderne, București 1972.

Maiorescu T., Traducerea lui Hamlet de D. Adolf Stern, "Timpul” 1877, no. 129, pp. 3-4.

Rebreanu L., Hamlet se reprezintă mâine pentru a suta oară, "Rampa" 1913, 2.02, pp. $1-2$.

Shakespeare W., Amlet, Prințul de la Dania. O tragodie in cinci perdele. După Sakespeer, I. Barac (transl.), Library of the Romanian Academy, Ms. 209, n.d.

Shakespeare W., Hamlet, $3^{\text {rd }}$ ed., Oxford 1988.

Shakespeare W., Hamlet, in: Oeuvres dramatiques de Shakespeare, vol. 2, [Pierre-Prime-Félicien] Letourneur (trad. de l'anglais), Paris 1835.

Shakespeare W., Hamlet, principele Danemarcei; dramă in cinci acte si optu părți de la Shakespeare, D.P. Economu (transl.), București 1855.

Shakespeare W., Hamlet prințul Danemarcei. Tragedie in 5 acte, A. Stern (transl.), Bucuresci 1877.

Shakespeare W., Hamlet, tragedie in 5 acte si 13 tablouri, G. Manolescu (transl.), The National Theatre of Bucharest Library, Ms. 124, 1881.

Stern A., Din viața unui evreu-român, București 1915.

Stern A., Preface, in: W. Shakespeare, Hamlet prințul Danemarcei. Tragedie in 5 acte, A. Stern (transl.), București 1877.

Streinu V., Preface to Tragedia lui Hamlet, Prinț de Danemarca, București 1965.

Şhyperl T., Grigore Manolescu, București 1960, p. 237.

Şoimaru T., Grigore Manolescu, București 1960.

Venuti L., The Translator's Invisibility: A History of Translation, London-New York 2002.

Xenopol A.D., Hamlet Prințul Danemarcei, tragedie in 5 acte de William Shakespeare, A. Stern (tradusă), "Convorbiri Literare” 1877, no. 7, October, pp. 273-276.

Zaharia O.-A., The First Romanian Translations of Hamlet, "American, British and Canadian Studies" 2011, no. 17, pp. 106-120. 